\title{
Carbon Stable Isotope Analyses of Mosses- Comparisons of Bulk Organic Matter and Extracted Nitrocellulose
}

\author{
Grzegorz Skrzypek, a,b Adam Kałużny, ${ }^{\text {b }}$ Mariusz O. Jędrysek ${ }^{\mathrm{b}}$ \\ ${ }^{a}$ Department of Earth and Environmental Science, The University of Texas at San Antonio, San Antonio, \\ Texas, USA \\ ${ }^{\mathrm{b}}$ Laboratory of Isotope Geology and Geoecology, Institute of Geological Sciences, The University of \\ Wrocław, Wrocław, Poland
}

The commonly used technique for determination of plant stable carbon isotope composition is analysis of $\mathrm{CO}_{2}$ liberated during combustion of chemically extracted nitrocellulose or $\alpha$-cellulose. The $\delta^{13} \mathrm{C}$ of cellulose is usually accepted as a more reliable record of growth environment conditions compared with bulk plant material analysis. Unfortunately, cellulose extraction techniques are time-consuming, and usually require toxic chemicals such as toluene, chloroform, benzene, methanol, concentrated acids, etc. We tested the possibility of replacing nitrocellulose analysis with bulk organic analysis. Sphagnum and Polytrichum mosses collected along a vertical transect (altitudes 500 to $1400 \mathrm{~m}$ ), provided material for analysis in the wide range of $\delta^{13} \mathrm{C}$ : $-32.66 \%$ and $-26.20 \%$ for bulk organic matter and $-24.11 \%$ and $-31.86 \%$ for nitrocellulose. The correlation for $\delta^{13} \mathrm{C}$ value of extracted cellulose and $\delta^{13} \mathrm{C}$ values of bulk organic matter were very good $(>0.95)$. Our results suggested that $\delta^{13} \mathrm{C}$ analyses can be performed on bulk plant material instead of cellulose, without significant loss of information, at least for Polytrichum and Sphagnum mosses. Moreover, we confirmed that the extraction process of nitrocellulose did not cause any significant isotopic fractionation. (J Am Soc Mass Spectrom 2007, 18, 1453-1458) (C 2007 American Society for Mass Spectrometry

$\mathrm{T}$ The isotopic composition of organic matter $\left(\delta^{13} \mathrm{C}\right.$, $\delta^{18} \mathrm{O}$, and $\left.\delta \mathrm{D}\right)$ has a broad range of applications, including paleoclimatic and paleoenvironmental reconstruction. Cellulose is one of the most abundant and resistant organic compounds present in plants. It is, therefore, a compound commonly used for paleoenvironmental reconstruction [1, 2]. Its use as a paleoclimatic proxy comes from results of earlier studies finding a direct correlation between the isotopic composition of carbon, hydrogen, and oxygen cellulose and mean annual temperature [1, 3, 4]. However, other factors including partial pressure and $\delta^{13} \mathrm{C}$ value of atmospheric $\mathrm{CO}_{2}$, as well as relative humidity and amount of precipitation, have also been found to influence the carbon isotope composition of cellulose (e.g., [5-8]). Although most studies assessing the relationship between cellulose isotope data and environmental conditions have been performed on tree rings, studies based on material such as mosses, lichens, and liverworts are uncommon. Despite its great potential as a climatic archive, the usefulness of peat as a paleoclimate proxy is still uncertain. In addition to sedges, mosses are a major component of peat in bogs and fens which may be used as a register of past climates.

Address reprint requests to Dr. G. Skrzypek, Department of Earth and Environmental Science, The University of Texas at San Antonio, One UTSA Circle, San Antonio, 78249 Texas, USA. E-mail: buki@ing.uni.wroc.pl
Unlike vascular plants, mosses employ a simpler physiological water-use strategy because they lack stomata and vascular tissue. In Sphagnum mosses, the photosynthetic cell is surrounded by so-called hyaline cells, which form significant water reservoirs. Due to these attributes, mosses cannot regulate their carbon uptake, which differentiates them from vascular plants [9]. Nonvascular plants can be very useful for stable isotope environmental studies because of this simplification in the physiology, e.g., the important fractionation for carbon isotope composition of vascular plants, due to the so-called "stomata effect", does not exist and neither does isotopic fractionation due, to wood formation [9].

Most theories about the decay of plant matter were developed from observations in soil science rather than from peat studies [10]. Early diagenetic processes decompose labile plant material rapidly in aerobic soil environments with adequate water supplies. Oxidative and hydrolytic biodegradation of this dead plant material by microorganisms (mainly fungi and bacteria) is believed to be a primary source of humic substances $[10,11]$. Plant cellulose is probably the most isotopically stable chemical compound, even under conditions of partial decomposition [1, 12-14]. Nevertheless, the primary isotopic plant composition can also be well preserved in bulk organic matter, especially in acid bog or fen conditions [14]. Indeed, cellulose extracted from 
plant and sediment is commonly used as the most reliable register of $\delta^{13} \mathrm{C}, \delta^{18} \mathrm{O}$, and $\delta \mathrm{D}$ isotope signals formed during photosynthesis.

In general, plant organic matter mainly consists of cellulose $(15 \%-50 \%)$, hemicellulose $(10 \%-40 \%)$, lignin $(5 \%-30 \%)$, proteins $(2 \%-15 \%)$, and lipids [15]. Dry Sphagnum organic matter mainly consists of cellulose $(\sim 43 \%)$, including three major types: $\alpha$-cellulose $(\sim 20 \%), \beta$-cellulose $(\sim 7 \%)$ and $\gamma$-cellulose $(\sim 15 \%)$ [16].

The question of whether stable isotopes can be analyzed on whole wood instead of cellulose has been indirectly addressed by many authors (e.g., [17-19], as well as studied in detail by Harlow et al. [20]. The question, however, was not considered in the case of mosses. Only Menot and Burns [21] have done the very first comparative studies based on 24 samples of various moss species. The generally postulated necessity of extracting cellulose is discussed in this paper, and it seems not to be required (at least for mosses).

Laboratories all over the world have developed various modifications of cellulose extraction methods, but all these methods were based on the very first studies by Green [22]. In principle, two major varieties of these techniques are widely used: the method of $\alpha$-cellulose extraction, the most common (e.g., [23]), and the cellulose extraction method with nitration (e.g., [1, 24]). The cellulose nitration method is also used for hydrogen stable isotope analysis, and gives very high reproducibility. This process, however, is more complicated and time-consuming.

All $\alpha$-cellulose techniques have been based on multiple chemical treatments with [22]: ${ }^{\circ} \operatorname{acetic}^{\circ}$ acid $^{\circ}$ and sodium chlorite at $70{ }^{\circ} \mathrm{C}$, sodium hydroxide $(17 \%)$, with addition of $\mathrm{HCl}(10 \%)$ and acetic acid (10\%). However, each laboratory did not use a Soxhlet apparatus for extractive removal. Even when it was used, not all the same organic solvents were applied. Among recently published papers, the most commonly used organic solvents were (1) 2:1 benzene-methanol mixture (24 h) and $^{\circ}$ acetone ${ }^{\circ}\left(24^{\circ} \mathrm{h}\right)^{\circ}$ by $^{\circ}$ Zanazzi $^{\circ}$ and ${ }^{\circ}$ Mora $^{\circ}[25]^{\circ}$ modified

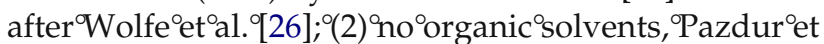

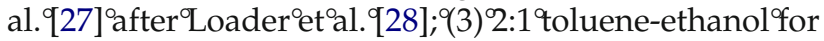

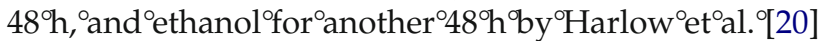
after ${ }^{\circ}$ Borella ${ }^{\circ} t^{\circ}$ al. $.^{\circ}[19]^{\circ}{ }^{\circ}(4)^{\circ} 1: 1^{\circ}$ toluene-ethanol ${ }^{\circ} 14^{\circ} \mathrm{h}^{\circ}$ or ${ }^{\circ} 8$ to ${ }^{\circ} 10^{\circ} \mathrm{h}^{\circ}$ by $^{\circ}$ Menot $^{\circ}$ and $^{\circ}$ Burns $^{\circ}[21]^{\circ}$ after $^{\circ}$ Brenninkmeijer [29]; (5) ${ }^{\circ}$ multiple ${ }^{\circ}$ ethanol ${ }^{\circ}(99 \%)^{\circ}$ washing ${ }^{\circ}$ and $^{\circ}$ acetone ${ }^{\circ y}$

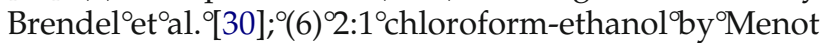
and $^{\circ}$ Burns $^{\circ}[21]^{\circ}$ after $^{\circ}$ Price $^{\circ}$ et $^{\circ}$ al $^{\circ}[31]^{\circ}$ and $^{\circ}$ Wise $^{\circ}$ and $\mathrm{D}^{\prime}$ Addieco ${ }^{\circ}[32]$.

Borella ${ }^{\circ} t^{\circ}{ }^{\circ}{ }^{\circ}{ }^{\circ}[23]^{\circ}{ }^{\circ}$ commended ${ }^{\circ}$ the ${ }^{\circ}$ last ${ }^{\circ}$ listed ${ }^{\circ}$ procedure (6) for mosses. A general evaluation and comparison of some of these listed techniques was done by Sheu ${ }^{\circ}$ and ${ }^{\circ} \mathrm{Chiu}^{\circ}[33]^{\circ}$ and $^{\circ}$ Borella ${ }^{\circ} \mathrm{et}^{\circ} \mathrm{al} . .^{\circ}[23]^{\circ}$; nevertheless, the difference between bulk material and extracted cellulose was studied for wood only and cellulose nitration has not been studied.

All techniques of cellulose extraction are timeconsuming and require toxic chemicals; therefore an alternative is desired. If possible, whole plant analysis could be used, provided there is no significant loss of information. The purpose of this research was to compare the carbon stable isotope composition of whole plant and extracted cellulose from selected moss samples. Our aim was to calibrate the $\delta^{13} \mathrm{C}$ bulk and $\delta^{13} \mathrm{C}$ nitrocellulose relation. The environmental causes of presented $\delta^{13} \mathrm{C}$ value variation for mosses were a subject ${ }^{\circ}$ of $^{\circ}$ other $^{\circ}$ publications $^{\circ}\left[2,{ }^{\circ} 34\right] .^{\circ}$ The $^{\circ}$ stable $^{\circ}$ isotopic analyses were performed at the Laboratory for Stable Isotope Geology and Geoecology, the University of Wrocław.

\section{Experimental Methods and Materials}

Samples of two moss species, Sphagnum girgensohnii Russow and Polytrichum commune Hedw., were collected from northern hillsides in the Karkonosze Mountains, (vertical transect 739-1393 m) and Izerskie Mountains (500-1100 m) SW Poland during two field seasons (July and October 2004). Among 18 sampling points, one point located at Hala Izerska was selected for extended ${ }^{\circ}$ studies ${ }^{\circ}[34]^{\circ},{ }^{\circ}$ where ${ }^{\circ}$ besides $^{\circ}$ Sphagnum girgensohnii and Polytrichum commune, the five other most common bog plant species, Carex enchinata, Molinia caerulea, Eriophoroum vaginatum, Sphagnum fallax, Sphagnum majus, and Sphagnum papillosum were collected.

The whole live plant samples (about 2 to $3 \mathrm{~g}$ dry matter each) were stored in the freezer $\left(-20^{\circ} \mathrm{C}\right)$ after collection. The proper botanical field identification of plant species was confirmed in the laboratory based on morphological features. After washing with distilled water, each sample was divided in two parts. Part one, intended for bulk organic matter preparation, was dried under vacuum and then milled to a fine powder. Part two was used for chemical extraction of cellulose.

The cellulose was extracted from the moss and vascular plant samples following the modified tech-

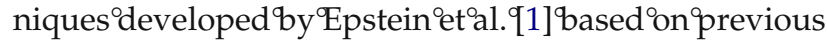
studies ${ }^{\circ}[16] .{ }^{\circ}$ The $^{\circ}$ preparation $^{\circ}$ consisted $^{\circ}$ of $^{\circ}$ three ${ }^{\circ}$ major steps: (1) multiple chemical treatments, (2) nitrification, (3) dissolution and precipitation of nitrocellulose. The samples were vacuum-dried after each step.

During the first step, lipids were removed by washing with a 1:1 benzene-methanol mixture for $24 \mathrm{~h}$. Subsequently, samples were washed with distilled water and mixed with acetone for $24 \mathrm{~h}$. Then they were rinsed with water and $\mathrm{HCl}(4 \%)$ and again washed with distilled water and boiled $(1 \mathrm{~h})$. Lignin was removed by treating the samples with acetic acid and sodium chlorite at $70^{\circ} \mathrm{C}$, which was repeated five times in 45 min intervals. Samples were then well rinsed with distilled water again. Hemicellulose was removed by treating samples with $17 \%$ solution of sodium hydroxide for $1 \mathrm{~h}$. After rinsing with distilled water, the samples were treated with $10 \%$ solution of acetic acid for $10 \mathrm{~min}$. Samples were rinsed with water, placed in desiccators and vacuum-dried. This first step is very similar to the technique described for moss $\delta^{18} \mathrm{O}^{\circ}$ analyzed ${ }^{\circ} y^{\circ} Z^{2}$ anazzi ${ }^{\circ}$ and $^{\circ}$ Mora $^{\circ}[25]^{\circ}$ developed ${ }^{\circ}$ after Green ${ }^{\circ}[22]^{\circ}$ and $^{\circ} \mathrm{Wolfe}^{\circ} \mathrm{et}^{\circ} \mathrm{al} . .^{\circ}[26]^{\text {. }}$ 
Table 1. Summary of regression estimates. The model using $\delta^{13} \mathrm{C}$ values of bulk organic carbon (x) to predict $\delta^{13} \mathrm{C}$ of nitrocellulose (y). In all cases the null hypothesis was that, slope (a) equals to one and intercept (b) equals zero. The relationship was described with a simple linear model $\mathrm{y}=\mathrm{ax}+\mathrm{b}$

\begin{tabular}{|c|c|c|c|c|c|c|c|c|}
\hline & $\begin{array}{c}\text { Location/ } \\
\text { sampling period }\end{array}$ & $\mathrm{n}$ & a ( \pm st. error) & $P a \neq 1$ & b ( \pm st. error) & $P b \neq 0$ & $\mathrm{R}^{2}$ & RMSE \\
\hline \multirow[t]{5}{*}{ Polytrichum } & Izery/1 & 10 & $0.97 \pm 0.07$ & 0.67 & $0.06 \pm 1.82$ & 0.97 & 0.96 & 0.14 \\
\hline & Izery/2 & 11 & $1.05 \pm 0.06$ & 0.42 & $2.91 \pm 1.74$ & 0.12 & 0.97 & 0.14 \\
\hline & Karkonosze/1 & 9 & $1.02 \pm 0.07$ & 0.78 & $2.23 \pm 2.08$ & 0.31 & 0.96 & 0.28 \\
\hline & Karkonosze/2 & 8 & $1.12 \pm 0.07$ & 0.13 & $5.27 \pm 2.00$ & $0.03^{*}$ & 0.98 & 0.30 \\
\hline & All above & 38 & $1.04 \pm 0.03$ & 0.19 & $2.84 \pm 0.95$ & $0.01 *$ & 0.96 & 0.24 \\
\hline \multirow[t]{5}{*}{ Sphagnum } & Izery/1 & 10 & $1.05 \pm 0.08$ & 0.55 & $2.05 \pm 2.16$ & 0.37 & 0.96 & 0.24 \\
\hline & Izery/2 & 11 & $1.11 \pm 0.09$ & 0.25 & $4.20 \pm 2.52$ & 0.13 & 0.95 & 0.28 \\
\hline & Karkonosze/1 & 9 & $0.97 \pm 0.04$ & 0.47 & $-0.26 \pm 1.22$ & 0.84 & 0.99 & 0.24 \\
\hline & Karkonosze/2 & 9 & $1.01 \pm 0.08$ & 0.90 & $0.73 \pm 2.34$ & 0.76 & 0.97 & 0.28 \\
\hline & All above & 39 & $1.02 \pm 0.04$ & 0.62 & $1.18 \pm 1.04$ & 0.26 & 0.96 & 0.30 \\
\hline \multirow[t]{3}{*}{ All plants } & Hala Izerska/1 & 7 & $1.31 \pm 0.09$ & $0.01 *$ & $8.96 \pm 2.48$ & $0.01 *$ & 0.97 & 0.17 \\
\hline & Hala Izerska/2 & 8 & $1.17 \pm 0.09$ & 0.10 & $5.80 \pm 2.47$ & $0.05^{*}$ & 0.96 & 0.26 \\
\hline & All above & 15 & $1.18 \pm 0.12$ & 0.16 & $5.73 \pm 3.14$ & 0.09 & 0.89 & 0.31 \\
\hline
\end{tabular}

Sampling periods: (1) July 2004, (2) October 2004. In total 3 outliers from 39 points for Sphagnum and 3 from 38 points for Polytrichum are abandoned for root mean square error (RMSE) calculations. $P$-values are calculated for two-tailed $t$-test, evaluated at $\alpha=0.05$, statistically significant tests are flagged with an asterisk $(*)$.

During the second step, dry samples where nitrated using nitric acid $\left(\mathrm{HNO}_{3} \mathrm{100 \%}\right.$, Merck catalog no. $1.00455)$ at $5{ }^{\circ} \mathrm{C}$ for $48 \mathrm{~h}$, according to the modified procedure ${ }^{\circ}$ of $^{\circ}$ Epstein $^{\circ}$ et $^{\circ}$ al. $^{\circ}[1]^{\circ}$ based $^{\circ}$ on $^{\circ}$ Goring $^{\circ}$ and $\operatorname{Timmell}^{\circ}[35]^{\circ}$ and $^{\circ}$ Alexander $^{\circ}$ and $^{\circ}$ Mitchell $^{\circ}[36]^{\circ}{ }^{\circ}$ The nitrated samples were washed with distilled water and mixed with methanol for $6 \mathrm{~h}$ and again washed with distilled water, and then vacuum-dried.

The nitrated product still might have contained traces of nitrated lignin and hemicellulose besides nitrocellulose. During the third step of preparation, essentially pure nitrocellulose was extracted by dissolving $^{\circ}$ in $^{\circ}$ acetone $^{\circ}[35]^{\circ} .^{\circ}$ After $^{\circ}$ centrifugation $^{\circ}$ and decantation, the nitrocellulose was precipitated from the solution by quickly adding distilled water. The white pure fluffy nitrocellulose was well rinsed with distilled water and dried under vacuum.

$\mathrm{As}^{\circ} \mathrm{was}^{\circ} \mathrm{shown}^{\circ} \mathrm{by}^{\circ} \mathrm{Timmell}^{\circ}[37]^{\circ}$, the $^{\circ}$ nitration ${ }^{\circ}$ procedure extracts the same yields for cellulose as does the sodium $^{\circ}{ }^{\text {chlorination }}{ }^{\circ}$ technique, ${ }^{\circ}$ e.g., ${ }^{\circ}[16]^{\circ}{ }^{\circ}$ The $^{\circ}$ experiments, ${ }^{\circ}$ which ${ }^{\circ}$ were ${ }^{\circ}$ done $^{\circ}$ by $^{\circ}{ }^{\circ}$ Epstein ${ }^{\circ} e^{\circ}{ }^{\circ} l^{\circ}[1]^{\circ}$ and ${ }^{\circ}$ Feng et ${ }^{\circ}$ al. ${ }^{\circ}[12]^{\circ}{ }^{\circ}$ confirm $^{\circ}$ that ${ }^{\circ}$ the ${ }^{\circ}$ advantage ${ }^{\circ}$ of $^{\circ}$ the ${ }^{\circ}$ nitration technique is that ${ }^{\circ}$ the ${ }^{\circ}$ exchangeable ${ }^{\circ} \mathrm{OH}$ hydrogen ${ }^{9}[38]^{\circ}$ in cellulose is replaced by nitrates during the esterifications, leaving the cellulose carbon-bound hydrogen unaffected. Therefore, the $\alpha$-cellulose extraction technique, although suitable for $\delta^{18} \mathrm{O}$, is not proper for $\delta \mathrm{D}$ analysis due to the presence of exchangeable hydrogen.

All stable isotope analyses were carried out using an off-line preparation system technique used for maximum precision. About 3 to $5 \mathrm{mg}$ of pure nitrocellulose or bulk plant samples were combusted with $\mathrm{CuO}$ wire in $^{\circ} \mathrm{a}^{\circ}$ sealed $^{\circ}$ quartz $^{\circ}$ tube, ${ }^{\circ}$ under $^{\circ}$ vacuum ${ }^{\circ} \mathrm{at}^{\circ} 900^{\circ} \mathrm{C}^{\circ}[14]$. The $\mathrm{CO}_{2}$ gas produced was cryogenically purified offline (liquid nitrogen and dry ice + ethanol mixture) and introduced into an isotope ratio mass spectrometer (IRMS; Finnigan-Mat Delta E/dual inlet, Bremen, Germany) for stable carbon isotope ratio analysis. The $\delta^{13} \mathrm{C}$ values were normalized against NBS22 and USGS24 international standards (distributed by the International Atomic Energy Agency, Vienna) and then reported relative to the Vienna Pee Dee Belemnite (VPDB) scale with precision $\pm 0.05 \%$. The $\delta^{13} \mathrm{C}_{\mathrm{VPDB}}$ value is defined as the relative difference, in parts per thousand (\%o), between the isotope ratio of the sample and the VPDB standard.

\section{Results and Discussion}

The stable carbon isotopic composition $\left(\delta^{13} \mathrm{C}_{\mathrm{VPDB}}\right)$ of mosses collected along selected transects varied due to different growth period temperatures observed at different ${ }^{\circ}$ altitudes ${ }^{\circ}\left[2,{ }^{\circ} 34\right] .{ }^{\circ}$ The $^{\circ}$ selection ${ }^{\circ}$ of $^{\circ}$ such $^{\circ}$ sampling points provided desirable material characterized by significantly different isotopic composition. The $\delta^{13} \mathrm{C}$ values for Sphagnum varied from $-32.66 \%$ to $-26.20 \%$ o (bulk organic matter) and from $-31.86 \%$ to $-25.03 \%$ (nitrocellulose). A similar range was observed for Polytrichum, from $-32.18 \%$ to $-26.22 \%$ o (bulk organic matter) and from $-30.51 \%$ to $-24.11 \%$ (nitrocellulose). The correlations between pairs of $\delta^{13} \mathrm{C}$ values for nitrocellulose and for bulk organic matter (for each moss sample) were analyzed in four scopes: two sampling periods (1st period in July or 2nd period October) and two locations (Karkonosze or Izerskie Mountains.).

A very high coefficient of determination $\left(R^{2}\right)$ was observed for each pair $\delta^{13} C_{\text {bulk }}-\delta^{13} C_{\text {nitrocellulose }}$ The $\mathrm{R}^{2}$ factors for Karkonosze equal: 0.96, 0.98, 0.99, and 0.97 for Polytrichum (July), Polytrichum (October), Sphagnum (July), ${ }^{\circ}$ Sphagnum (October), ${ }^{\circ}$ respectively ${ }^{\circ}$ (Table 1 1). ${ }^{\circ}$ Only one sample, which did not match the trend, was excluded. Similarly, very high $\mathrm{R}^{2}$-factors were observed for Izerskie: 0.96, 0.97, 0.96, and 0.95 for Polytrichum (July), Polytrichum (October), Sphagnum (July), Sphagnum (October), respectively (also, only one sample was excluded). The overall $R^{2}$ factor for both places and 

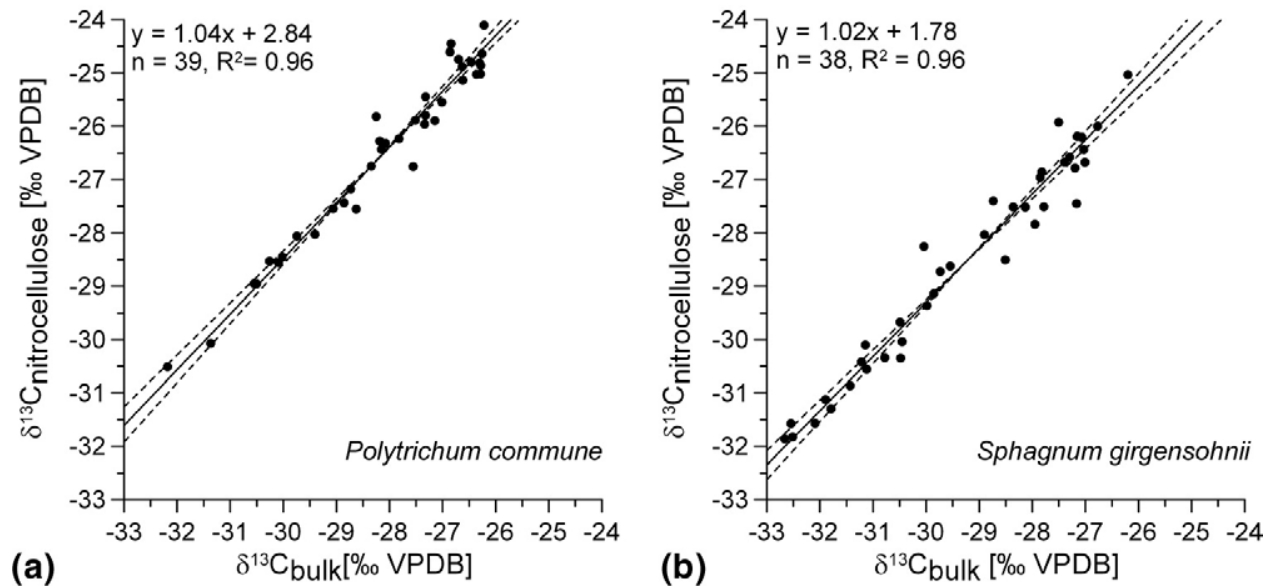

Figure 1. Representative $\delta^{13} \mathrm{C}$-values in bulk plant material versus $\delta^{13} \mathrm{C}$-values in nitrocellulose from Polytrichum commune (a) and Sphagnum girgensohnii (b). Summary for both regions Izerskie and Karkonosze Mountains and both sampling periods (July and October). The solid line represents the model and the dashed lines represent 95\% confidence intervals of the model (reduced major axis regression).

sampling periods was equal to 0.96 for all Polytrichum samples and was the same for all Sphagnum samples (Figure ${ }^{\circ}{ }^{\circ}$ Table ${ }^{\circ} 1$ ).

The $^{\circ}$ regression $^{\circ} \operatorname{model}^{\circ}\left(\right.$ summarized $^{\circ}$ in $^{\circ}$ Table $^{\circ} 1$ ) using $\delta^{13} \mathrm{C}_{\text {bulk }}$ to predict $\delta^{13} \mathrm{C}_{\text {nitrocellulose }}$ provided best fit (reduced major axis regression). Besides the high correlations $\left(R^{2}\right)$, the calculated slopes for the linear regression lines for both moss species, locations and periods were significantly similar to unity ( $P$-values from 0.13 to 0.90 , two-tailed $t$-test), and observed differences were smaller then the highest standard errors for slope $(<0.09)$. The overall slope for all Polytrichum samples was $1.04(n=38, P=0.19)$ and for Sphagnum $1.02(n=39, P=0.62)$. The intercepts were significantly similar to zero for Sphagnum (all cases) and for Polytrichum samples collected in Izerskie (July and October) and Karkonosze (July), $P$-values from 0.12 to 0.97 . The intercept for Polytrichum (October) was different from zero $(P=0.03)$. The overall intercept for Polytrichum was $2.84( \pm 0.95$, $P=0.01)$, and for Sphagnum $1.18( \pm 1.04, P=0.26)$ $\left(\right.$ Table $\left.^{\circ} 1\right){ }^{\circ}{ }^{\circ} \mathrm{No}^{\circ}$ significant ${ }^{\circ}$ differences ${ }^{\circ}$ were $^{\circ}$ observed between groups of mosses collected during different seasons $(P$-values range from 0.3 to $0.8, t$-unpaired test). ${ }^{9} t^{\circ}{ }^{\circ}{ }^{\circ} s^{\circ}$ evident ${ }^{\circ}$ from ${ }^{\circ}$ the ${ }^{\circ}$ data $^{\circ}$ presented $^{\circ}{ }^{\circ}{ }^{\circ}$ Figure $1^{\circ}$ that, ${ }^{\circ}$ in ${ }^{\circ}$ general, ${ }^{\circ}$ the ${ }^{\circ}$ averag $e^{\circ} \delta^{13} \mathrm{C}^{\circ}$ value ${ }^{\circ}$ of ${ }^{\circ}$ nitrocellulose was about $1.6 \%$ more positive versus bulk organic matter for Polytrichum and $0.7 \%$ for Sphagnum. The standard deviations for these calculated offsets were $0.40(n=38)$ and $0.41(n=39)$, respectively. This rule seems to be valid for the entire analyzed $\delta^{13} \mathrm{C}$ range, however prediction of $\delta^{13} C_{\text {nitrocellulose }}$ from $\delta^{13} C_{\text {bulk }}$ may introduce an uncertainty. The root mean square error (RMSE) for all analyzed pairs of $\delta^{13} \mathrm{C}$ values (bulk- cellulose) varies from $0.14 \%$ to $0.30 \%$. The introduced uncertainty (RMSE) is within the typically accepted precision for the EA technique (elemental analyzer in continuous flow) which is about $\pm 0.15 \%$ o $(1 \sigma)$. Despite these differences and introduced uncertainty, the relative variation of the $\delta^{13} \mathrm{C}$ trend (e.g., between locations) can be observed for bulk organic matter as well as for the extracted nitrocellulose (e.g., Sphagnum in the Izerskie ${ }^{\circ}$ Mountains, ${ }^{\circ}$ (Figure ${ }^{\circ}$ ).

These results are in general agreement with the previous preliminary studies published by Menot and Burns ${ }^{\circ}[21],{ }^{\circ}$ where ${ }^{\circ}$ they ${ }^{\circ}$ also ${ }^{\circ}$ observed ${ }^{\circ}{ }^{\circ}$ high ${ }^{\circ}$ correlation $\left(R^{2}=0.87\right)$ and slope (about 0.9), but a different intercept $(-0.85)$ for $\alpha$-cellulose from 24 unclassified moss species.

In addition, all the most common bog plant species were collected at Hala Izerska. These include (1) mosses: Sphagnum girgensohnii, Polytrichum commune, Sphagnum fallax, Sphagnum majus, Sphagnum papillosum, and (2) vascular plants: Carex enchinata, Molinia caerulea, Eriophoroum vaginatum (all these species are C3 photosynthesis). A high correlation $\left(R^{2}=0.97\right.$ and 0.96$)$ was also found for samples of various species of Polytrichum

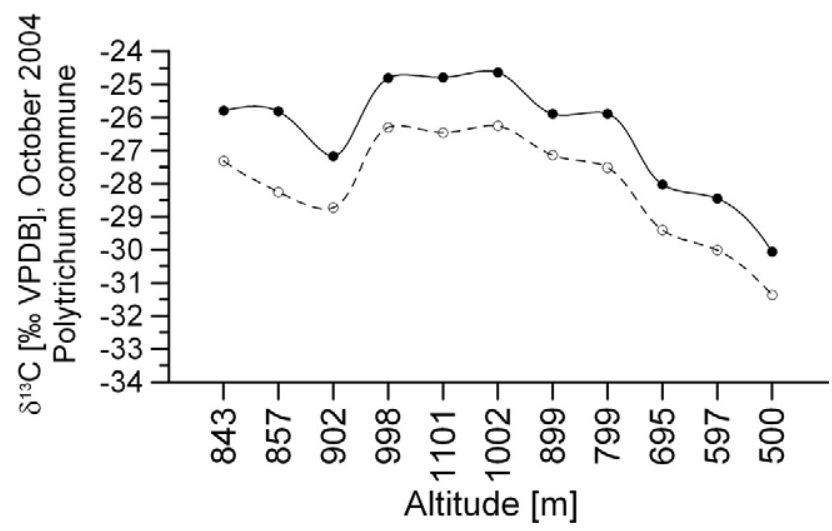

Figure 2. Example of $\delta^{13} \mathrm{C}$-values variations in vertical transect from Izerskie Mountains. Bulk plant material $\delta^{13} \mathrm{C}$-values (dashed line) versus $\delta^{13} \mathrm{C}$-values in nitrocellulose (solid line). 

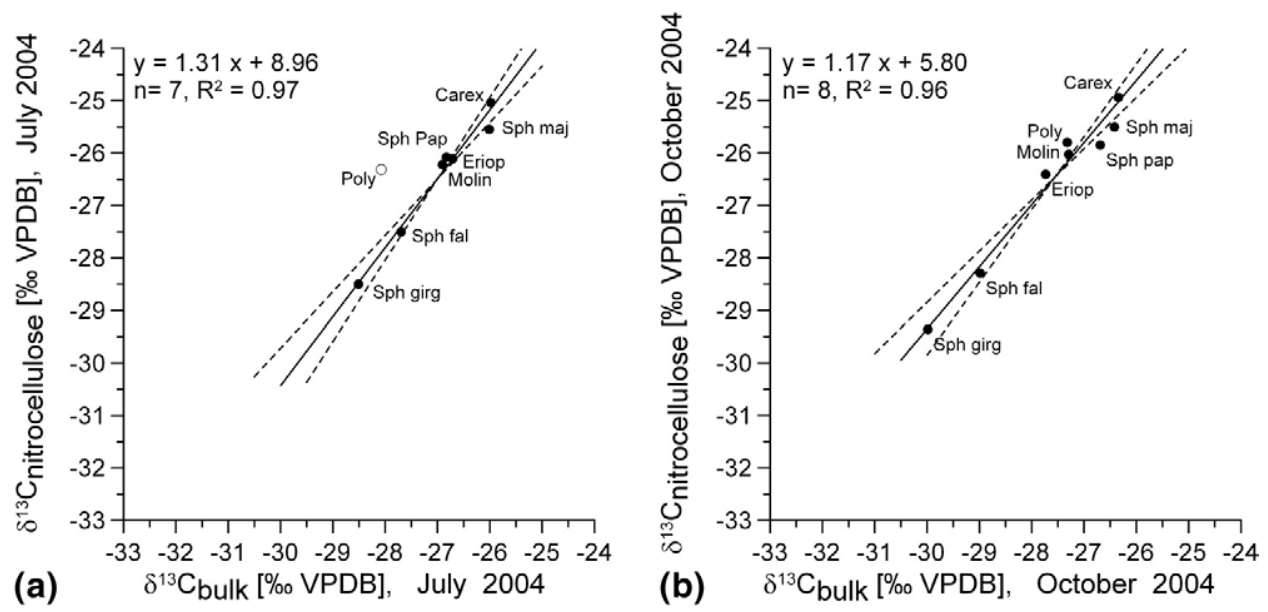

Figure 3. Representative $\delta^{13} \mathrm{C}$-values in bulk plant material versus $\delta^{13} \mathrm{C}$-values in nitrocellulose from selected plants, collected in July (a) and October (b) 2004 at Hala Izerska bog, SW Poland. Plants: Sphagnum girgensohnii (Sph girg), Polytrichum commune (Poly), Carex enchinata (Carex), Molinia caerulea (Molin), Eriophoroum vaginatum (Eriop), Sphagnum fallax (Sph fal), Sphagnum majus (Sph maj), Sphagnum papillosum (Sph pap). At plot A, one sample (Poly) excluded (open symbol). The solid line represents the model and the dashed lines represent $95 \%$ confidence intervals of the model (reduced major axis regression).

and Sphagnum. It was not surprising that $\delta^{13} \mathrm{C}$ for all moss species fit this linear regression because they have very similar physiology and grow in only slightly different conditions. No significant differences were observed for groups of plant samples collected during different seasons ( $P$-values from 0.48 to 0.82 ). On other hand, it is very interesting that $\delta^{13} \mathrm{C}$ of vascular plants such as sedges, grasses, and cotton-grass followed the same $^{\circ}$ regression $^{\circ}$ line $^{\circ}\left(\right.$ Figure $\left.^{\circ} 3\right) .{ }^{\circ}$ However,${ }^{\circ}{ }^{\circ}$ wide $^{\circ}$ confidence interval for slope and interval for intercept were observed $^{\circ}$ for $^{\circ}$ mosses $^{\circ}\left(\right.$ Figures $^{\circ} 1^{\circ}$ and $\left.^{\circ} 3\right){ }^{\circ}$ The $^{\circ}$ slope $^{\circ}$ is significantly different from unity for samples collected in July $(P<0.01)$ but not significantly different for samples collected in October $(P=0.10)$. However, the relative difference between slopes (1.31 for July and 1.17 for October) was within the range of two standard error $\pm^{\circ} 0.09^{\circ}\left(\right.$ Table $\left.^{\circ} 1\right)$.

We may assume that the isotope fractionation during the metabolic process of cellulose formation during plant growth in each analyzed plant species was affected by the same controlling factor, probably mainly ${ }^{\circ}$ by $^{\circ}$ temperature $^{\circ}\left[2,{ }^{\circ} 34\right] .{ }^{\circ}$ Because $^{\circ}$ of ${ }^{\circ}$ that, ${ }^{\circ}$ the same differences between $\delta^{13} \mathrm{C}$ values for bulk organic matter and $\delta^{13} \mathrm{C}$ of nitrocellulose could be observed for all collected species, despite completely different types of plants (average $0.83 \%$ ). Previously, Menot ${ }^{\circ}$ and ${ }^{\circ}$ Burns ${ }^{\circ}[21]^{\circ}$ stated ${ }^{\circ}$ that ${ }^{\circ} i^{\circ}{ }^{\circ}$ was ${ }^{\circ}$ not ${ }^{\circ}$ proper ${ }^{\circ}$ to consider vascular and nonvascular plants together because vascular species contain varying amounts of cellulose and noncellulose organic fractions. Regardless of this conclusion, we suggest that considering the vascular plants together with nonvascular plants in this case could be relevant. The influence of the temperature on the difference between carbon isotopic composition of nitrocellulose and bulk organic matter could be more crucial then physiological differences ${ }^{\circ}$ between $^{\circ}$ analyzed $^{\circ}$ species $^{\circ}\left[2,{ }^{\circ} 34\right]$.

\section{Conclusions}

The correlation factors between pairs of $\delta^{13} \mathrm{C}$ values: extracted nitrocellulose-bulk organic matter were very high for all analyzed plants $\left(R^{2}\right.$ factors were $\left.\geq 0.95\right)$. These results suggested that the extraction process of nitrocellulose did not cause any crucial isotopic fractionation; the slope of linear regression equals 1.02 (Sphagnum) and 1.04 (Polytrichum). The $\delta^{13} \mathrm{C}$ values of extracted nitrocellulose and bulk plant organic matter were not equal. A more or less consistent difference between $\delta^{13} \mathrm{C}$ for extracted nitrocellulose and bulk organic matter of $0.7 \%$ for Sphagnum and $1.6 \%$ for Polytrichum was observed. These observations support the conclusion that $\delta^{13} \mathrm{C}$ analysis can be performed on bulk plant material instead of cellulose, without significant loss of information, at least for Polytrichum and Sphagnum mosses. This will reduce cost and time of analysis as well as the use of toxic chemicals.

\section{Acknowledgments}

The authors are grateful to Eric Swanson and Benjamin Harlow for their critical reading of the text and valuable remarks as well as Sława Bruder and Kristi Salazar for text correction. Appreciation is also expressed to Bronisław Wojtun for botanical identification. The authors thank reviewers for suggestions and comments that helped to improve the statistical justification of data analyses. This study was realized as a part of the scientific grant no. 2P04G 004, 26 (founded by the Ministry of Science and Higher Education Poland), and were supported from University of Wrocław (2022/ W/ING and 1017/S/ING). 


\section{References}

1. Epstein, S.; Yapp, C. J.; Hall, J. H. Determination of the D/H Ratios of Nonexchangeable Hydrogen in Cellulose Extracted from Aquatic and Land Plants. Earth Planet Sci. Lett. 1976, 30, 241-251.

2. Skrzypek, G.; Jedrysek, M. O. ${ }^{13} \mathrm{C} /{ }^{12} \mathrm{C}$ Ratio in Peat Cores: Record of Past Climates. In Environmental Chemistry-Green Chemistry and Pollutants in Ecosystems; Lichtfouse, E.; Schwarzbauer, J.; Robert, D., Eds.; Springer-Verlag: Berlin, Heidelberg, Germany 2005; pp 65-73.

3. Libby, L. M.; Pandolfi, L. J. Temperature Dependence of Isotope Ratios in Tree Rings. Proceedings of the National Academy of Sciences; June 1974, $71,2482-2486$

4. Epstein, S.; Thompson, P.; Yapp, C. J. Oxygen and Hydrogen Isotopic Ratios in Plant Cellulose. Science 1977, 198, 1209-1215.

5. Ramesh, R.; Bhattacharya, S. K.; Gopalan, K. Climatic Correlations in the Stable Isotope Records of Silver Fir (Abies pindrow) Tree from Kashmir, India. Earth Planet Sci. Lett. 1986, 79, 66-74.

6. Terwilliger, V. J.; DeNiro, M. J. Hydrogen Isotope Fractionation in Wood-Producing Avocado Seedlings: Biological Constraints to Paleoclimatic Interpretations of $\delta \mathrm{D}$ Values in Tree Ring Cellulose Nitrate. Geochim. Cosmochim. Acta 1995, 24, 5199-5207.

7. Lipp, J.; Trimborn, P.; Edwards, T.; Waisel, Y.; Yakir, D. Climatic effects on the $\delta^{18} \mathrm{O}$ and $\delta^{13} \mathrm{C}$ of Cellulose in the desert tree Tamarix jordanis. Geochim. Cosmochim. Acta 1996, 60, 3305-3309.

8. Anderson, W. T.; Bernasconi, S. M.; McKenzie, J. A. Oxygen and Carbon Isotopic Record of Climatic Variability in Tree Ring Cellulose (Picea abies): An example from Central Switzerland. J. Geophys. Res. 1998, 103, 31625-31636.

9. Rydin, H. Competition and Niche Separation in Sphagnum. Can. J. Bot. 1986, 64, 1817-1824.

10. Stevenson, F. J. Humus Chemistry-Genesis, Composition, Reactions, 2nd ed. John Wiley and Sons: New York, 1994, p. 512.

11. Kracht, O.; Gleixner, G. Isotope Analysis of Pyrolysis Products from Sphagnum peat and Dissolved Organic Matter from Bog Water. Org. Geochem. 2000, 31, 645-654.

12. Feng, X.; Krishnamurthy, R.V.; Epstein, S. Determination of D/H Ratios of Nonexchangeable Hydrogen in Cellulose: A Method Based on the Cellulose-Water Exchange Reaction. Geochim. Cosmochim. Acta 57, 4249, 1993, 4256.

13. Schleser, G. H.; Frielingsdorf, J.; Blair, A. Carbon Isotope Behavior in Wood and Cellulose During Artificial aging. Chem. Geol. 1999, 158, 121-130

14. Jędrysek, M. O.; Skrzypek, G. Hydrogen, Carbon, and Sulphur Isotope Ratios in Peat: The Role of Diagenessis and Water Regimes in Reconstruction of Past Climates. Env. Chem. Lett. 2005, 2Q, 179-183.

15. Haider, K. Biochemie des Bodens; 1st ed.; Enke Verlag: Stuttgart, 1996, p. 174.

16. Plank, N. The Nature of Cellulose in Sphagnum. Am. J. Bot. 1946, 33, 335-337.

17. Francey, R. J. Carbon Isotope Measurements in Baseline Air, Forest Canopy Air, and Plants. In: The Changing Carbon Cycle; Trabalka, J. R.; Reichle, D. E., Eds.; Springer Verlag: New York 1986; pp 160-174.

18. Leavitt, S. W.; Long, A. Seasonal Stable Carbon Isotope Variability in Tree Rings: Possible Paleoenvironmental Signals. Chem. Geol. 1991, 87, $59-70$

19. Borella, S.; Leuenberger, M.; Saurer, M.; Siegwolf, R. Reducing Uncertainties in $\delta^{13} \mathrm{C}$ Analysis of Tree Ring: Pooling, Milling, and Cellulose Extraction. J. Geophys. Res. 1998, 103, 19519-19526.
20. Harlow, A. B.; Marshall, J. D.; Robinson, A. P. A Multi-Species Comparison of ${ }^{13} \mathrm{C}$ from Whole Wood, Extractive-Free Wood, and Holocellulose. Tree Physiol. 2006, 26, 767-774.

21. Menot, G.; Burns, S. J. Carbon Isotopes in Ombrogenic Peat Bog Plants as Climatic Indicators: Calibration from an Altitudinal Transect in Switzerland. Org. Geochem. 2001, 32, 233-245.

22. Green, J. W. Wood Cellulose. In: Methods in Carbohydrate Chemistry, Vol III; Whistler, R. L., Ed.; Academic Press: New York, 1963; pp 9-20.

23. Borella, S.; Menot, G.; Leuenberger, M. Sample Homogeneity and Cellulose Extraction from Plant Tissue for Sstable Isotope Analyses. In Handbook of Stable Isotope Analytical Techniques, Vol. I; Groot, P. A., Ed.; Elsevier: Amsterdam, 2005; pp 507-522.

24. DeNiro, M. J. The Effects of Different Methods of Preparing Cellulose Nitrated on the Determination of the D/H Ratios of Nonexchangeable Hydrogen of Cellulose. Earth Planet Sci. Lett. 1981, 54, 177-185.

25. Zanazzi, A.; Mora, G. Paleoclimatic Implications of the Relationship Between Oxygen Isotope Ratios of Moss Cellulose and Source Water in Wetlands of Lake Superior. Chem. Geol. 2005, 222, 281-291.

26. Wolfe, B. B.; Edwards, T. W. D.; Beuning, K. R .M.; Elgood, R. J. Carbon and Oxygen Isotope Analysis of Lake Sediment Cellulose: Methods and Applications. In Tracking Environmental Change Using Lake Sediments: Physical and Chemical Techniques, Developments in Paleoenvironmental Research, Vol. II; Last, W. M.; Smol, P., Eds.; Kluwer Academic Publishers: Dordrecht, The Netherlands, 2001; pp 373-400.

27. Pazdur, A.; Korput, S.; Fogtman, M.; Szczepanek, M.; Halas, S.; Krapiec, M.; Mszychowska-Krapiec, E. Carbon-13 in $\alpha$-Cellulose of Oak Latewood (Jẹdrzejów, Southern Poland) During the Maunder Minimum. Geol. Quart. 2005, 4(2), 165-172.

28. Loader, N. I.; Robertson, I.; Barker, A. C. Switsur, V. R. Waterhouse, J. S. A Modified Method for the Batch Processing of Small Whole Wood Samples to $\alpha$-Cellulose. Chem. Geol. 1997, 136, 313-317.

29. Brenninkmeijer, C. A. M. Deuterium, ${ }^{18} \mathrm{O}$, and ${ }^{13} \mathrm{C}$ in Tree Rings and Peat Deposits in Relation to Climate; Ph.D. Thesis, University of Groningen, 1983.

30. Brendel, O.; Iannetta, P. P. M.; Stewart, D. A Rapid and Simple Method of Isolate Pure $\alpha$-Cellulose. Phytochem. Anal. 2000, 11, 7-10.

31. Price, G. D.; McKenzie, J. E.; Pilcher, J. R.; Hoper, W. T. Carbon-Isotope Variation in Sphagnum from Hummock-Hollow Complex: Implications for Holocene Climate Reconstruction. Holocene 1997, 7, 229-233.

32. Wise, L. E.; D'Addieco, M. M. Chlorite Holocellulose, Its Fractionation and Bearing on Summative Wood Analysis and on Studies in the Hemicellulose. Paper Trade J. 1946, 122, 35.

33. Sheu, D. D.; Chiu, C. H. Evaluation of Cellulose Extraction Procedures for Stable Isotope Measurements in Tree Ring Research. Int. Environ. Anal. Chem. 1995, 59, 59-67.

34. Skrzypek, G.; Kałużny, A.; Wojtuń, B.; Jędrysek, M. O. The Carbon Stable Isotopic Composition of Mosses: The Record of Temperature Variation. Org. Geochem. 2006, in press.

35. Goring, D. A.; Timmell, T. E. Molecular Properties of a Native Wood Cellulose. Seven Papperstidn. 1960, 63, 524.

36. Alexander, W. J.; Mitchell, R. L. Rapid Measurement of Cellulose Viscosity by the Nitration Method. Anal. Chem. 1946, 21, 1497.

37. Timmell, T. E. Nitration as a Means of Isolating the $\alpha$-Cellulose Component of Wood. TAPPI 1957, 40, 30.

38. Heuser, E. Cellulose chemistry; J. Wiley and Sons Inc., Chapman and Hall Ltd.: New York, London, 1944: p. 660. 